Research Article

\title{
A Study to Assess the Knowledge and Expressed Practices regarding Breast Self-Examination among Women in a Selected Area of Haryana
}

\author{
Suchhanda Bhattacharya', Renu $^{2}$ \\ 1,2Tutor, Rufaida College of Nursing, Jamia Hamdard, New Delhi, India. \\ DOI: https://doi.org/10.24321/2455.9318.202029
}

\section{I $\quad \mathbf{N} \quad \mathbf{F} \quad \mathbf{O}$}

\section{Corresponding Author:}

Suchhanda Bhattacharya, Rufaida College of Nursing, Jamia Hamdard, New Delhi, India.

E-mail Id:

suchhanda.joarder@gmail.com

Orcid Id:

https://orcid.org/0000-0001-5450-5491

How to cite this article:

Bhattacharya S, Renu. A Study to Assess the Knowledge and Expressed Practices Regarding Breast Self- Examination among Women in a Selected Area of Haryana. Int J Nurs Midwif Res 2020; 7(4): 13-17.

Date of Submission: 2020-12-03

Date of Acceptance: 2020-12-22

\section{$\begin{array}{llllllll}\mathbf{A} & \mathbf{B} & \mathbf{S} & \mathbf{T} & \mathbf{R} & \mathbf{A} & \mathbf{C} & \mathbf{T}\end{array}$}

\begin{abstract}
Breast self-examination is a very simple screening tool for breast cancer. It requires minimal training to be imparted to women. They are instructed to detect any asymmetry with the other breast in terms of a lump, change in breast shape or of the overlying skin (puckering), any abnormal discharge from the nipples \&/or any breast lesion that does not heal easily. Teaching women about this importance of breast selfexamination is a core subject of community nursing. It was therefore thought important to assess the background knowledge regarding the same amongst women of a selected area in Haryana. The aim of the study was to assess the knowledge and expressed practices regarding breast self-examination among women in a selected area of Haryana. A sample of 50 women was chosen. Data collection was done by using Google form questionnaire after assessing their willingness and ability to participate in this survey by filling up this online form. After assessing the knowledge level, it was found that $80 \%(n=40)$ were having adequate knowledge regarding breast self-examination and $20 \%(n=10)$ were having inadequate knowledge regarding breast self-examination. 52\% of the women $(n=26)$ were practicing breast self-examination and rest were not. Awareness regarding breast self-examination was adequate in the sample studied. However, the practice of performing the same was present in only about $50 \%$ of the women in the above-mentioned sample. The findings of the study highlights the need for educational programs to create awareness among women regarding regular breast screening behavior.
\end{abstract}

Keywords: Breast Self-Examination, Expressed Practices, Knowledge, Women

\section{Introduction}

Cancer is a group of diseases involving abnormal cell growth with the potential to invade or spread to other parts of the body. ${ }^{1}$ They form a subset of neoplasm. A neoplasm or tumor is a group of cells that have undergone unregulated growth and forms a mass or lump, but may be distributed diffusely. ${ }^{2}$ About $90-95 \%$ of cases are due to genetic mutations from environmental and lifestyle factors. The remaining $5-10 \%$ are due to inherited genetics. ${ }^{3}$ 
Breast cancer has been mentioned in almost every period of recorded history.

According to WHO and Global Cancer Statistics in 2018, 9.6 million people die from cancer every year and 70 percent of cancer deaths occur in low-to-middle income countries. India ranks third in cancer cases after China and the US. ${ }^{4}$

Cancer is a group of diseases involving abnormal cell growth with the potential to invade or spread to other parts of the body. ${ }^{1}$ They form a subset of neoplasm. A neoplasm or tumor is a group of cells that have undergone unregulated growth and forms a mass or lump, but may be distributed diffusely. ${ }^{2}$ About $90-95 \%$ of cases are due to genetic mutations from environmental and lifestyle factors. The remaining 5-10\% are due to inherited genetics. ${ }^{3}$ Breast cancer has been mentioned in almost every period of recorded history.

According to WHO and Global Cancer Statistics in 2018, 9.6 million people die from cancer every year and 70 percent of cancer deaths occur in low-to-middle income countries. India ranks third in cancer cases after China and the US. ${ }^{4}$

Breast cancer is a disease in which cells in the breast grow out of control. Signs of breast cancer may include a lump in the breast, a change in breast shape, dimpling of the skin, fluid coming from the nipple, a newly-inverted nipple, or a red or scaly patch of skin. ${ }^{5}$ In those with distant spread of disease, there may be bone pain, swollen lymph nodes, shortness of breath, or yellow skin. ${ }^{6}$

Risk factors for developing breast cancer include being female, obesity, lack of exercise, drinking alcohol, hormone replacement therapy during menopause, ionizing radiation, early age 25 at first menstruation, having children late or not at all, older age, prior history of breast cancer, and family history. ${ }^{7}$

Early detection and treatment are the main interventions of disease control. The earlier a disease is diagnosed and treated the better it is from the point of view of prognosis and preventing the occurrence of further damage. ${ }^{8}$

The stage of the breast cancer is the most important component of traditional classification methods of breast cancer, because it has a greater effect on the prognosis than the other consideration size, local involvement, lymph node status and whether metastatic disease is present. The higher the stage at diagnosis, the poorer the prognosis. The stage is raised by the invasiveness of disease to lymph nodes, chest wall, skin or beyond, and the aggressiveness of the cancer cells. ${ }^{9}$

Knowing how to perform, when to perform and position to perform breast self-examination and having a perception that breast self-examination is important and useful to detect breast cancer. ${ }^{10}$

\section{Materials \& Methods}

A descriptive survey was conducted at Sadar Thana Police Quarters, Sonipat, Haryana among women with in the age group of 20-60 years to assess knowledge and expressed practices regarding breast self-examination. The assessment was limited to one-time assessment of knowledge and expressed practices among women. 50 women aged 2060 years were selected using convenience sampling in the study.

Anonymity and confidentiality of the responses was assured. Ethical committee clearance from the institutional ethical board was obtained.

Data was collected by a self-administered pre-tested close ended questionnaire for assessing the knowledge and expressed practice questionnaire. The tools were validated via content validity by submitting the tools 7 experts from the field of nursing. The questionnaire comprised 30 items (13 items on knowledge, 17 items on expressed practices). As of current situation, the whole world is battling with COVID, therefore the data collection technique used was online mode. The data collection was done via Google forms. The questions were in English language and translated in Hindi language.

The data was analyzed using inferential statistical analysis. The demographic variables were described using frequency distribution \& percentages. For knowledge \& expressed practices questionnaire, every correct response is awarded with a score of " 1 " and every incorrect response is given a score of " 0 ". Based on the score of knowledge questionnaire, the scores between 9-13 was considered as adequate knowledge and a score less than 8 was considered as inadequate knowledge. For expressed practices, the range score of 11-17 was considered as adequate practices and score less than 10 represents inadequate expressed practices.

\section{Result}

This study represented the knowledge and expressed practices of women aged between 20-60 years regarding breast self-examination. The frequency and percentage was calculated for the demographic variables and were depicted in Table 1.

Overall it was observed that majority of the women (80\%) were having adequate knowledge regarding breast selfexamination and $20 \%$ depicted inadequate knowledge. The histogram represents the knowledge scores of women regarding Breast self-examination. 
Table I.Frequency and percentage distribution of the sample according to their various demographic profiles

$(n=50)$

\begin{tabular}{|c|c|c|c|}
\hline $\begin{array}{l}\text { S. } \\
\text { No. }\end{array}$ & Demographic profile & $\begin{array}{l}\text { Frequ- } \\
\text { ency }\end{array}$ & $\begin{array}{c}\text { Percentage } \\
\text { (\%) }\end{array}$ \\
\hline \multirow[t]{5}{*}{1.} & Age & & \\
\hline & 20-30 years & 21 & $42 \%$ \\
\hline & $31-40$ years & 14 & $28 \%$ \\
\hline & $41-50$ years & 11 & $22 \%$ \\
\hline & $51-60$ years & 4 & $8 \%$ \\
\hline \multirow[t]{5}{*}{2.} & Education & & \\
\hline & Primary & 1 & $2 \%$ \\
\hline & Secondary & 1 & $2 \%$ \\
\hline & Senior Secondary & 5 & $10 \%$ \\
\hline & Graduation and above & 43 & $86 \%$ \\
\hline \multirow[t]{5}{*}{3.} & Marital status & & \\
\hline & Unmarried & 16 & $32 \%$ \\
\hline & Married & 32 & $64 \%$ \\
\hline & Divorced & 0 & $0 \%$ \\
\hline & Widowed & 2 & $4 \%$ \\
\hline \multirow[t]{5}{*}{4.} & Number of children & & \\
\hline & 0 & 20 & $40 \%$ \\
\hline & 1 & 4 & $8 \%$ \\
\hline & 2 & 21 & $42 \%$ \\
\hline & 3 or more & 5 & $10 \%$ \\
\hline \multirow[t]{5}{*}{5.} & $\begin{array}{l}\text { Family Monthly Income } \\
\text { (in rupees) }\end{array}$ & & \\
\hline & $5,000-15,000$ & 5 & $10 \%$ \\
\hline & $15,001-25,000$ & 4 & $8 \%$ \\
\hline & $25,001-35,000$ & 12 & $24 \%$ \\
\hline & 35,001 and above & 29 & $58 \%$ \\
\hline \multirow[t]{5}{*}{6.} & Age attaining menarche & & \\
\hline & 9 years & 1 & $2 \%$ \\
\hline & $10-11$ years & 3 & $6 \%$ \\
\hline & $12-13$ years & 25 & $50 \%$ \\
\hline & $14-15$ years & 21 & $42 \%$ \\
\hline \multirow[t]{3}{*}{7.} & Dietary habits & & \\
\hline & Vegetarians & 47 & $94 \%$ \\
\hline & Non-vegetarians & 3 & $6 \%$ \\
\hline 8. & $\begin{array}{c}\text { What are your sources } \\
\text { of information about } \\
\text { breast cancer? }\end{array}$ & & \\
\hline & Friends and Neighbors & 6 & $12 \%$ \\
\hline
\end{tabular}

\begin{tabular}{|c|c|c|c|}
\hline & Relatives & 8 & $16 \%$ \\
\hline & Health workers & 12 & $24 \%$ \\
\hline & T.V / Radio/ social media & 24 & $48 \%$ \\
\hline \multirow[t]{3}{*}{9.} & $\begin{array}{l}\text { Any history of breast } \\
\text { cancer in your family? }\end{array}$ & & \\
\hline & Yes & 5 & $10 \%$ \\
\hline & No & 45 & $90 \%$ \\
\hline \multirow[t]{3}{*}{10.} & $\begin{array}{c}\text { Do you have any } \\
\text { previous knowledge } \\
\text { about breast cancer? }\end{array}$ & & \\
\hline & Yes & 26 & $52 \%$ \\
\hline & No & 24 & $48 \%$ \\
\hline \multirow[t]{3}{*}{11.} & $\begin{array}{c}\text { Have you ever } \\
\text { practiced Breast self - } \\
\text { examination? }\end{array}$ & & \\
\hline & Yes & 12 & $24 \%$ \\
\hline & No & 38 & $76 \%$ \\
\hline
\end{tabular}

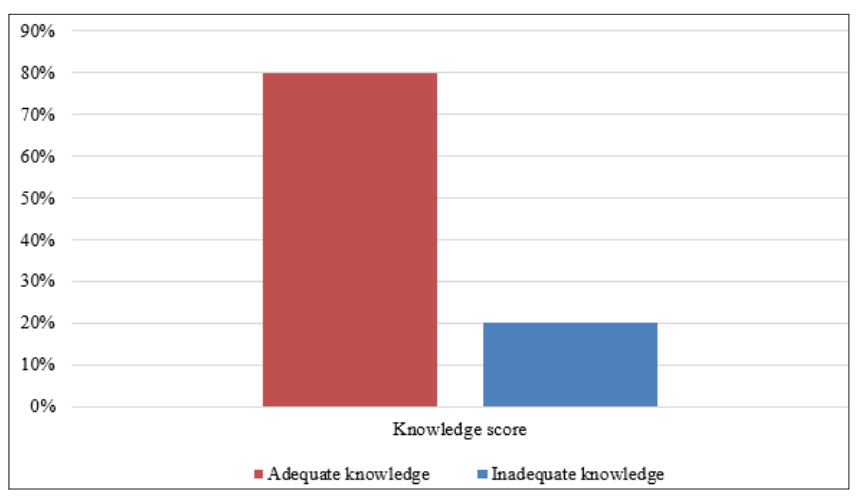

Figure I.Knowledge score of breast self - examination of women

The obtained range of score was 6-13 out of the possible range of score $0-13$. The mean, median, mode and standard deviation were calculated and found out to be 9.76, 9, 9 \& 1.89 respectively.

Table 2(a).Mean, Median, mode and standard deviation of knowledge score

$(n=50)$

\begin{tabular}{|c|c|c|l|l|l|c|}
\hline Variable & $\begin{array}{c}\text { Pos- } \\
\text { sible } \\
\text { range } \\
\text { of } \\
\text { score }\end{array}$ & $\begin{array}{c}\text { Obta- } \\
\text { ined } \\
\text { range } \\
\text { of } \\
\text { score }\end{array}$ & Mean & $\begin{array}{c}\text { Me- } \\
\text { dian }\end{array}$ & $\begin{array}{c}\text { Mo- } \\
\text { de }\end{array}$ & $\begin{array}{c}\text { Stan- } \\
\text { dard } \\
\text { devi- } \\
\text { ation }\end{array}$ \\
\hline $\begin{array}{c}\text { Know- } \\
\text { ledge } \\
\text { Score }\end{array}$ & $0-13$ & $6-13$ & 9.76 & 9 & 9 & 1.89 \\
\hline
\end{tabular}

The expressed practices on Breast Self-Examination among 
women in a selected area of Haryana were also assessed. A range score of more than $75 \%$ was considered as adequate expressed practices and $52 \%$ of the participants were found practicing adequate practices regarding breast selfexamination, where as $48 \%$ of women were practicing inadequate expressed practices.

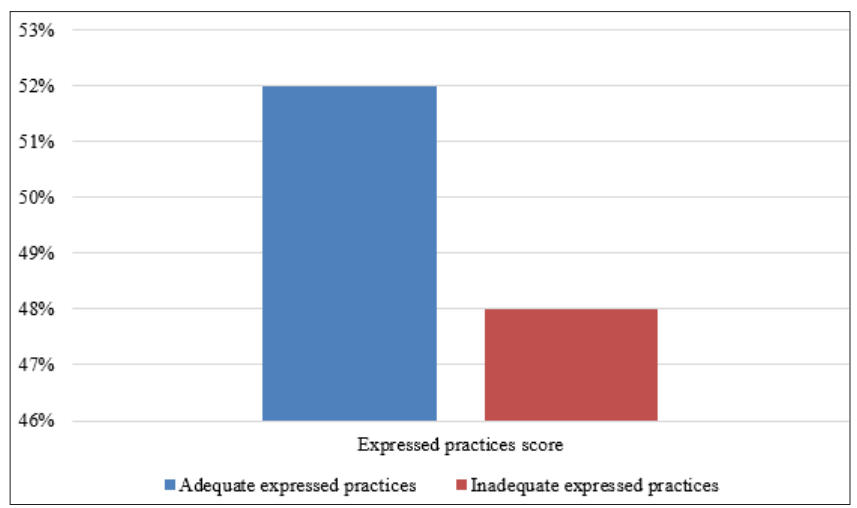

Figure 2.Expressed practice score of breast selfexamination of women

The possible range score for expressed practices regarding breast self-examination was $0-17$. The expressed practices score of women ranges from 4 while maximum score is 15. The data indicated that the mean of obtained range of score was 9.52, the median was 10 , the mode was 7 and the standard deviation was 3.65 .

Table 2(b). Mean, Median, mode and standard deviation of expressed practice score

$(n=50)$

\begin{tabular}{|c|c|c|c|c|c|c|}
\hline Variable & $\begin{array}{c}\text { Poss- } \\
\text { ible } \\
\text { range } \\
\text { of } \\
\text { score }\end{array}$ & $\begin{array}{c}\text { Obta- } \\
\text { ined } \\
\text { range } \\
\text { of } \\
\text { score }\end{array}$ & Mean & $\begin{array}{c}\text { Med- } \\
\text { ian }\end{array}$ & $\begin{array}{c}\text { Mo- } \\
\text { de }\end{array}$ & $\begin{array}{c}\text { Stan- } \\
\text { dard } \\
\text { devi- } \\
\text { ation }\end{array}$ \\
\hline $\begin{array}{c}\text { Expressed } \\
\text { practices }\end{array}$ & $0-17$ & $4-15$ & 9.52 & 10 & 7 & 3.65 \\
\hline
\end{tabular}

The findings of the study focus revealed the disparity between the knowledge and expressed practices among women regarding breast self-examination.

\section{Conclusion}

The study concluded that majority of the participants had adequate knowledge $(80 \%)$ regarding breast selfexamination. The findings also suggested that majority of the participants had adequate expressed practices (52\%) regarding breast self-examination. The findings highlighted the need of awareness towards the practicing of breast self-examination. A higher number of participants had knowledge regarding the breast self-examination but the expressed practice were not at satisfactory level.

\section{Discussion}

As breast self-examination is the most simple and cost effective technique to identify the breast cancer, the awareness regarding it possess higher need in the present day. The study results are similar to the research conducted by Dr. Kousar Sideeq et al. regarding knowledge, attitude and practice about breast self-examination among ethnic Kashmiri females in Jammu \& Kashmir, India. The women were in the age group of 20-60 years. The results depicted that only $5.6 \%$ has self-examined their breast which is similar to our study as only half of the participants were practicing breast self-examination. ${ }^{8}$

\section{Acknowledgement}

We would like to express our gratitude towards all the participants who were taken their time from their busy schedule to contribute in this study and gave us the quality data for the study which is extremely helpful for the future as well. All the experts who have validated our survey tool for the study which helps us to gather the quality data. The authors would like to express their sincere thanks to the students of 3rd Year BSc Hons. Nursing at Rufaida College of Nursing for having conducted this online survey.

\section{Funding}

The research received no external funding.

\section{Conflict of Interest}

The authors whose names are listed above (in the starting) certify that they there is no conflict of interest. The authors have not received any financial interest or non-financial interest (such as personal or professional relationships, affiliation or beliefs) in the subject matter or materials discussed in the manuscript.

\section{References}

1. Cancer. Defining Cancer. National Cancer Institute. 2018. Available from: https://en.wikipedia.org/wiki/ Cancer.

2. American Cancer Society. Cancer Glossary. 2013. Available from: https://www.cancer.org/cancer/ glossary.html.

3. Cancer is a preventable disease that require major lifestyle modification. Pharmaceutical Research. Introduction of Cancer 2008; 25: 2200.

4. Bray F, Ferlay J, Soerjomataram I et al. Cancer. World health organisation (article). Cancer incidence and mortality worldwide. IARC Cancer Base No. 11. 2018. Available from: https://www.who.int/news-room/ fact-sheets/detail/cancer.

5. Breast Cancer. Available from: https://en.m.wikipedia. org/wiki/Breast_cancer.

6. Park K. Textbook of Preventive and social medicine. $22^{\text {nd }}$ ed. 
7. Birhane K, Alemayehu M, Anawte B, et al. Practices of Breast Self-Examination and Associated Factors among Female Debre Berhan University Students. Hindawi. Available from: https://www.hindawi.com/journals/ ijbc/2017/8026297/.

8. Sideeq K, Ayoub T, Sailm Khan SM. Breast selfexamination: assessing its knowledge attitude and practice among ethnic Kashmiri females. Research Gate. (Cited august 2017) Available from: https://www. researchgate.net/publication/319258727_Breast_ selfexamination_assessing_its_knowledge_attitude_ and_practice_among_ethnic_Kashmi 